\title{
Biodiversity within the subfamily Alyssinae (Hymenoptera, Braconidae) in the Natural Park Peñas de Aya (Spain)
}

\author{
Francisco Javier Peris-Felipo ${ }^{1} \&$ Ricardo Jiménez-Peydró ${ }^{1}$
}

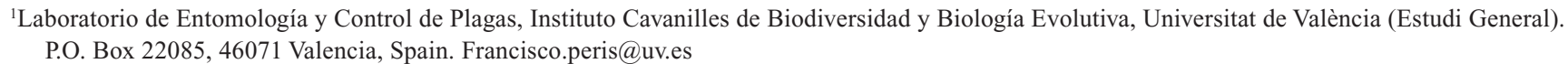

\begin{abstract}
Biodiversity within the subfamily Alyssinae (Hymenoptera, Braconidae) in the Natural Park Peñas de Aya (Spain). The study of parasitoid Hymenoptera is of significance for the assessment of diversity in a given area because of their role in the regulation of insects populations. The present work analyses diversity within Alysiinae (Hymenoptera, Braconidae) in the Forested Estate of Artikutza, located in the Natural Park Peñas de Aya, western Pyrenees, Spain. Collection of specimens was spread over two years and was carried out in two different habitats: mixed forest and beech forest. A total of 2,270 specimens, belonging to 22 separate genera, were captured. Subsequently, alpha, beta and gamma diversities were analysed, and the beech forest was proven to host greater diversity than the mixed forest. A sampling strategy was adopted for the analysis of Alysiinae phenology and its relationship with environmental climatic conditions; as a result, a direct relationship between phenology and temperature was attested.
\end{abstract}

KEYWORDS. Diversity; forest system, parasitoids; protected area; Pyrenees.

RESUMO. Biodiversidade na Alyssinae subfamília (Hymenoptera, Braconidae) no Parque Natural Peñas de Aya (Espanha). O estudo dos himenópteros parasitóides é significativo para uma avaliação da diversidade em determinada área por causa do seu papel no controle das populações de insetos. O presente trabalho analisa a diversidade no taxon Alysiinae (Himenóptero, Braconidae) na área de floresta de Artikutza, localizada no Parque Natural de Peñas de Aya, Pirinéus ocidentais, Espanha. A coleta de espécimes dividiu-se em dois anos e foi realizada em dois habitats diferentes: floresta mista e floresta de faias. No total, foram capturados 2.270 exemplares pertencentes a 22 gêneros distintos. Subsequentemente, as variedades alfa, beta e gama foram analisadas, comprovando-se que a floresta de faias apresenta uma diversidade maior que a floresta mista. Adotou-se a estratégia de amostra para análise da fenologia da Alysiinae e da sua relação com as condições climáticas ambientais, de onde se concluiu que existe uma relação direta entre a fenologia e a temperatura.

PALAVRAS-CHAVE. Área protegida; diversidade; parasitóides; Pirineus; sistema florestal.

In land environments, the information provided by arthropods can be very valuable for the adoption of measures aimed at guaranteeing the diversity and welfare of protected forests (Pyle et al. 1981; Pearson \& Cassola 1992; Kremen et al. 1993), especially insects with a high sensitivity to alterations in environmental resources and conditions. Parasitoid hymenoptera of the Braconidae family, with around 14,890 catalogued species, are especially pertinent in this respect due to their particular biology (Wharton et al. 1997).

Braconidae are the second largest family within Hymenoptera, the majority of species are primary parasitoids of immature stages of Lepidoptera, Coleoptera and Diptera (Sharkey 1993). These wasps are of enormous ecological interest because of their role in controlling the population of phytofagous insects, causing direct effects in the host species' population size and indirect ones in the diversity and survival of host plants (La Salle \& Gauld 1992; TorezanSilingardi 2011). Additionally, they can indicate presence or absence of those populations (Matthews 1974; LaSalle \& Gauld 1992). Finally, some species can also be relevant from an economic point of view due to their potential for pest control (González et al. 2000; Elpino-Campos et al. 2007).
Because of the type of relationship established between Braconidae populations and host species, and the effect that climatic factors and human activity possess upon this, we can consider that Braconidae (especially those adopting koinobiont strategies in which not paralyze its guest or only momentarily) are a valid parameter for the determination of human effect on these communities and the assessment of specific diversity within a region (Delfín \& Burgos 2000).

The subfamily Alysiinae, with 1,500 catalogued species worldwide, and including two tribes, Alysiini and Dacnusini, has a prominent position within the Braconidae family (Dolphin \& Quicke 2001). The Alysiini interact with a wide variety of cyclorrhapha hosts, often in humid habitats and ephemeral substrata, laying their eggs in the host's larvae or eggs. Dacnusini, by contrast, are almost exclusively specialised in leaf and stem miners, such as Agromyzidae, Ephydridae and Chloropidae. Specimens of the generas Aphaereta Förster, 1862 and Alysia Latreille, 1804, belonging to the Alysiini tribe, have been bred and freed in biological control programs involving Calliphoridae and Muscidae, while some Dacnusini have been successfully employed to control pests of leaf miners and Tephritidae (Wharton et al. 1998). 
Although many faunal and diversity studies around Braconidae have been carried out worldwide, for example in Brazil (Cirelli \& Penteado-Dias 2003; Scatolini \& PenteadoDias 2003) or Venezuela (Briceño et al. 2009), in the Iberian Peninsula (Andorra, Spain and Portugal) these communities have been insufficiently analysed (Nieves \& del Castillo 1991; Pujade-Villar 1996; Segade et al. 1997; Ros-Farré \& PujadeVillar 1998; González et al. 2000; Martínez de Murguía et al. 2001; Tomé et al. 2001), with the exception of a study about this family in the Pyrenees (Falcó-Garí et al. 2006).

Within this context, the present work analyses alpha, beta and gamma diversity of Alysiinae in the Forested Estate of Artikutza (Navarra), selected for its location, south-west Pyrenees, and its habitat which comprises alternating pine and beech forest and thus possesses enormous ecological value. Data on the subfamily's phenology and its relationship with environmental and climatic conditions are also offered.

\section{MATERIAL AND METHODS}

Area of study. The present faunal study on Alysiinae Braconidae population was carried out in the Natural Park Peñas de Aya (Guipuzcoa, Spain) located at the western end of the Pyrenees. This natural park has an extension of 6,913 ha, and a maximum altitude of $834 \mathrm{~m}$. Due to its large dimensions a study area of 5 ha was selected from within the Forested Estate of Artikutza (30TWN972868 U.T.M.). The estate lies at an altitude between 575 and $652 \mathrm{~m}$ (Martínez de Murguía et al. 2001) and has gone through frequent processes of deforestation and repopulation in the past, but is currently populated by two adjacent plant series: mixed forest and beech forest. The mixed forest is a repopulated secondary forest including Pinus sylvestris L., Quercus petraea L. and Fagus sylvatica L. On the other hand, the beech forest has been partially repopulated and is surrounded by other repopulated conifer forest. Other species are represented by isolated specimens, as Castanea sativa L., Taxus baccata L., Salix atrocinerea Brot., Fraxinus excelsior L., Betula celtiberica Rothm \& Vasc., Ulmus glabra Hud. and Sorbus aucuparia (L.) Crantz. The soil oligotrophic nature produces a poor shrubbery and herbaceous stratum, in which the following species should be highlighted: Ilex aquifolium L., Blechnum spicant (L.) Roth., Deschampsia flexuosa (L.) Trin., Vaccinium myrtillus L., Euphorbia amygdaloides L., Daphne laureola L., Oxalis acetosella L. and, in the brighter areas and clearing edges, Crataegus monogyna Jacq., Corylus avellana L., Pyrus cordata Desv., Malus sylvestris Miller, Pteridium aquilinum (L.) Kuhn., Erica vagans L. and Asphodelus albus Miller, among others.

The main climatic feature for the area is the high precipitation regime, between 1,500 and 2,800 mm. Rain is more abundant in winter, and scarcer during summer. The temperature is moderate, with an average between 8 and $17^{\circ} \mathrm{C}$ (Fig. 1).

For the identificacion of Alysiinae, the criteria indicated in Achterberg (1993), Tobias et al. (1986 a, b) and Wharton et al. (1997) were followed.

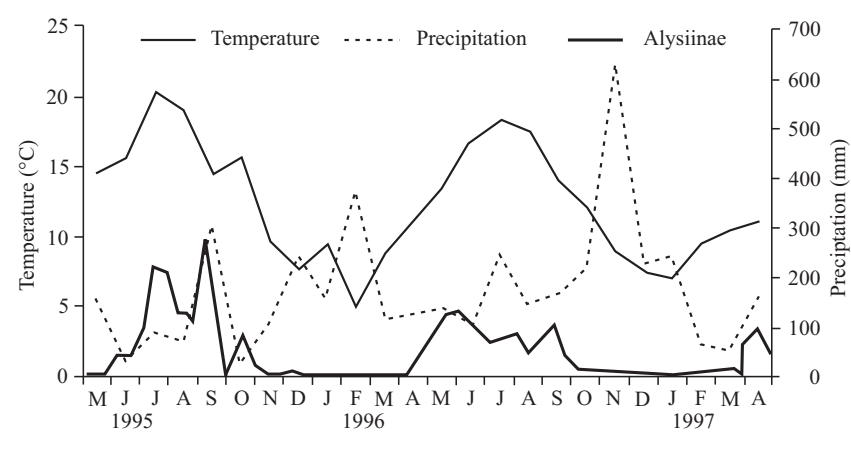

Fig. 1. Relationship between climatic conditions and Alysiinae phenology.

Sampling design and data collection. The sampling of parasitoid wasps was carried out with Malaise traps, Townes design, characterised for being bi-directional $(203 \mathrm{~cm}$ maximum height, $112 \mathrm{~cm}$ minimum, $122 \mathrm{~cm}$ wide and $183 \mathrm{~cm}$ long), and black in colour, with a white ceiling and fine mesh $(0.3 \mathrm{~mm})$. This trap works on the principle that many species of flying insects tend to adopt an ascending trajectory when confronted with an obstacle. By doing so, the insects end up in a jar full of preserving liquid that includes $75 \%$ of alcohol, $20 \%$ of distilled water and $5 \%$ acetic acid.

The sampling included the installation of three traps in each habitat: mixed forest (M-1, M-2 and M-3) and beech forest (H-1, H-2 and H-3). The heterogeneous distribution of trees and differences in slope gave each trap specific conditions, the main features of which were as follows: M-1: On the edge of a clearing; M-2: In open forest; M-3: Under a mature beech tree in an area mostly populated with pine trees; H-1: Under a large beech tree; H-2: Near a small clearing and surrounded by a layer of beech shrubs; H-3: Under the shade of a mature beech tree on a landing.

Sampling was carried out without interruption during a two-years period, from May 1995 to April 1997. During this period, jars were collected at intervals of 14 days, with the exception of seven occasions, in which they were collected after 28 days, with a total of 270 samples.

Data analysis. Once the Alysiinae specimens had been identified, alpha, beta and gamma biodiversity indexes for each trap and habitat were calculated, in order to gain insight into the richness, abundance, dominance and complementarity values for each area. Additionally, the phenological study of all captured specimens was undertaken, by comparing the climatic conditions on the sampling area in order to determine the possible relationship between temperature and the presence of Alysiinae.

Alpha diversity was measured by taxa richness, abundance and dominance.

Taxa richness: used for valuing richness on sampling areas. It was measured using the Margalef index (Moreno 2001).

Abundance: used for valuing faunal composition of a given area (Magurran 1991). This was measured using the Shannon index, because it measures equity, indicating the degree of uniformity in species representation (in order of abundance) while considering all samples (Moreno 2001; Magurran 1991; Villarreal et al. 2004).

Revista Brasileira de Entomologia 55(3): 406-410, setembro, 2011 
Dominance: genera occurrence or dominance value was calculated using the Simpson index, often used to measure species dominance values in a given community, its negative thus representing equity (Magurran 1991).

In order to measure beta diversity, the Jaccard and Complementarity indexes were used.

Jaccard index: relates the total amount of shared species with the total amount of exclusive species (Moreno 2001; Villarreal et al. 2004).

Complementarity index: indicates the degree of similarity in species composition and abundance between two or more communities (Moreno 2001; Villarreal et al. 2004).

Finally, the gamma diversity measurement indicates the diversity value of all environments under study, as expressed in the richness indexes for each area (alpha diversity) and beta diversity (Schluter \& Ricklefs 1993; Villarreal et al. 2004).

\section{RESULTS AND DISCUSSION}

During the sampling period, 78,229 specimens of hymenoptera were collected, including 3,534 specimens in the Braconidae family and 2,270 (64.23\%) in the Alysiinae subfamily.

The captured specimens fall into a total of 22 genera of Alysiinae: Alysia Latreille 1804, Aphaereta Förster 1862, Aristelix Nixon 1943, Asobara Förster 1862, Aspilota Förster 1862, Chorebus Haliday 1833, Coelinidea Viereck 1913, Coelinius Nees 1818, Coloneura Förster 1862, Cratospila Förster 1862, Dacnusa Haliday 1833, Dapsilarthra Förster 1862, Dinotrema Förster 1862, Exotela Förster 1862, Laotris Nixon 1943, Orthostigma Ratzeburg 1844, Pentapleura Förster 1862, Phaenocarpa Förster 1862, Synaldis Förster 1862, Synelix Förster 1862, Tates Nixon 1943 and Trachyusa Ruthe 1854 (Table I).

The number of genera indentified varies from habitat to habitat and from trap to trap. For example, 17 genera were identified in the mixed forest habitat (15 in M-1, 14 in M-2 and 11 in M-3), while 20 were identified in the beech forest habitat (12 in H-1, 15 in $\mathrm{H}-2$ and 14 in $\mathrm{H}-3$ ).

The genus Dinotrema was the most commonly captured, with 1,278 specimens, followed by Chorebus (338), Orthostigma (239) and Aspilota (139). The genus Dinotrema is noted for its cosmopolitism and its abundance within the Alysiinae (Wharton et al. 1997), as well as for being a primary parasitoid of Phoridae and Platypezidae (Diptera).

The abundance differed depending on the kind of forest observed, 1,593 specimens were captured in mixed forest ( 528 M-1, 550 M-2 and 485 M-3) while 707 were captured in beech forest $(243 \mathrm{H}-1,236 \mathrm{H}-2$ and $228 \mathrm{H}-3)$.

When calculating alpha, beta and gamma diversity values, each habitat and each trap must be considered separately.

Alpha diversity. According to our observations, beech forest is richer in number of genera represented, with $\mathrm{D}_{M g}=$ 2.896; against 2.176 in mixed forest. These values are so close because the number of genera identified in both habitats is
Table I. Distribution of Alysiinae specimens per habitat.

\begin{tabular}{|c|c|c|c|c|c|c|c|}
\hline Genera & M-1 & M-2 & M-3 & H-1 & $\mathrm{H}-2$ & $\mathrm{H}-3$ & Total \\
\hline Alysia & 11 & 0 & 1 & 0 & 0 & 1 & 13 \\
\hline Aphaereta & 0 & 0 & 0 & 0 & 0 & 1 & 1 \\
\hline Aristelix & 1 & 0 & 0 & 1 & 0 & 0 & 2 \\
\hline Asobara & 6 & 2 & 0 & 0 & 1 & 4 & 13 \\
\hline Aspilota & 41 & 19 & 25 & 16 & 11 & 27 & 139 \\
\hline Chorebus & 51 & 120 & 55 & 40 & 49 & 23 & 338 \\
\hline Coelinidea & 0 & 0 & 0 & 1 & 2 & 0 & 3 \\
\hline Coelinius & 0 & 2 & 1 & 0 & 1 & 1 & 5 \\
\hline Coloneura & 0 & 0 & 0 & 1 & 1 & 2 & 4 \\
\hline Cratospila & 8 & 5 & 4 & 4 & 4 & 2 & 27 \\
\hline Dacnusa & 49 & 5 & 8 & 4 & 10 & 16 & 92 \\
\hline Dapsilarthra & 8 & 2 & 2 & 2 & 1 & 2 & 17 \\
\hline Dinotrema & 302 & 320 & 311 & 119 & 113 & 113 & 1278 \\
\hline Exotela & 0 & 0 & 0 & 0 & 1 & 0 & 1 \\
\hline Laotris & 1 & 3 & 0 & 0 & 1 & 0 & 5 \\
\hline Orthostigma & 24 & 45 & 60 & 47 & 33 & 30 & 239 \\
\hline Pentapleura & 1 & 0 & 0 & 0 & 0 & 1 & 2 \\
\hline Phaenocarpa & 2 & 1 & 1 & 0 & 0 & 0 & 4 \\
\hline Synaldis & 15 & 23 & 17 & 7 & 7 & 5 & 74 \\
\hline Synelix & 0 & 1 & 0 & 0 & 0 & 0 & 1 \\
\hline Tates & 0 & 0 & 0 & 1 & 0 & 0 & 1 \\
\hline Trachyusa & 8 & 2 & 0 & 0 & 1 & 0 & 11 \\
\hline Total & 528 & 550 & 485 & 243 & 236 & 228 & 2270 \\
\hline
\end{tabular}

also similar. On the other hand, at trap level, H-2 is the trap showing the greatest richness in number of genera, with $\mathrm{D}_{M g}=2.562$, followed by H-3 and M-1 (2.212 and 2.081 respectively) (Table II).

Table II. Diversity and abundance of Alysiinae captured.

\begin{tabular}{lcccccccc}
\hline & M-1 & M-2 & M-3 & H-1 & H-2 & H-3 & M & H \\
\hline Species & 109 & 4 & 4 & 3 & 12 & 9 & 10 & 17 \\
Specimens & 33 & 19 & 11 & 6 & 17 & 19 & 63 & 42 \\
Shannon I. & 1.526 & 1.136 & 1.241 & 0.8676 & 2.364 & 1.908 & 1.518 & 2.5 \\
Simpson I. & 0.6924 & 0.626 & 0.6777 & 0.5 & 0.8927 & 0.8033 & 0.7045 & 0.8889 \\
Margalef I. & 2.288 & 1.019 & 1.251 & 1.116 & 3.883 & 2.717 & 2.172 & 4.281 \\
\hline
\end{tabular}

For the analysis of proportional abundance, the ShannonWiener and the Simpson dominance indexes were calculated (Table II). According to the Shannon index (1.438 for mixed forest and 1.633 for beech forest), both habitats show a similar trend regarding distribution of dominant genera; significant differences are limited to rare genera, that is, those represented by a few specimens. The Simpson index reflects a similar picture $(0.6099$ for mixed forest and 0.7038 for beech forest). When analysing these values at trap level, H-3, H-2, M-1 and H-1 were observed to be the traps showing more equity $(1.639,1.607,1.515$ and 1.511 respectively), while in 
the Simpson index the ranking is H-3 (0.7043), H-2 (0.7027), H-1 (0.6898) and M-1 (0.6299).

Beta diversity. Beta diversity (similarity/dissimilarity) was obtained using values between the different areas under consideration, with the Jaccard index (Table III). The value obtained comparing both habitats $(0.681)$ shows again a certain degree of similarity between environments. At the trap level M-1/M-2 and M-2/H-2 (0.705) show the strongest similarity, while $\mathrm{M}-2 / \mathrm{H}-1$ are the least similar $(0.444)$.

Table III. Values of the Complementarity (C) and Jaccard index for Alysiinae in each trap.

\begin{tabular}{|c|c|c|c|c|c|c|}
\cline { 2 - 7 } \multicolumn{1}{c|}{} & M-1 & M-2 & M-3 & H-1 & H-2 & H-3 \\
\hline M-1 & & 0.400 & 0.272 & 0.083 & 0.222 & 0.428 \\
\hline M-2 & 0.600 & & 0.600 & 0.166 & 0.230 & 0.400 \\
\hline M-3 & 0.727 & 0.400 & & 0.166 & 0.142 & 0.272 \\
\hline H-1 & 0.916 & 0.833 & 0.833 & & 0.153 & 0.083 \\
\hline H-2 & 0.777 & 0.769 & 0.857 & 0.846 & & 0.294 \\
\hline H-3 & 0.571 & 0.600 & 0.727 & 0.916 & 0.705 & \\
\hline
\end{tabular}

On the other hand, the complementarity index (C) shows a low level of complementarity between mixed and beech forest (0.375) indicating that the genera present in both habitats are similar. On the other hand, at the trap level M-2/H-1 show a higher degree of complementarity, with a value of 0.555 , indicating differences in the genera collected, while M-2/H-2 show lower complementarity $(0.294)$ as a consequence of a similar representation of genera in both cases.

Gamma diversity. Gamma diversity at the habitat level reaches a value of 24.527 , largely contributed to by the beech forest habitat, which shows the bigger diversity with 22 collected genera. At the trap level, gamma diversity attains a value of 21.7323, as expressed in total number of genera identified in each community. According to these values, M-1 and $\mathrm{H}-2$ are the traps showing higher diversity with 15 genera, and M-3 was the fewer diverse, with 11.

The data collected were also used to analyse the seasonal evolution of Alysiinae. The results show that Alysiinae are present between late April and late October each year. Subsequently, the data was also used to assess the possible relationship between their presence and climatic conditions, no relationship could be attested between precipitation levels and number of captured Alysiinae, but a coincidence between rise in temperatures and increased numbers of captures could be certified.

Finally, after the analysis of all data collected and the estimation of alpha, beta and gamma diversity values in both habitats, mixed forest and beech forest, we conclude that the latter shows a higher diversity of Alysiinae than mixed forest, even though the number of captured specimens is clearly lower. We also conclude that the presence of this subfamily of Braconidae is connected with climatic conditions.

\section{ACKNOWLEDGMENTS}

We would like to thank Leticia Martínez de Murguia for the donation of the specimens of Braconidae Hymenoptera stored at the Laboratorio de Entomología y Control de Plagas of Valencia University for their analysis and identification.

\section{REFERENCES}

van Achterberg, C. 1993. Illustrated key to the subfamilies of the Braconidae (Hymenoptera: Ichneumonoidea). Zoologische Verhandelingen 283: 1-189.

Briceño, R.; D. Torres \& A. Zaldívar-Riverón. 2009. Primer reporte de la familia Braconidae (Hymenoptera: Ichneumonoidea) en los parques Cerro Saroche y Terepaima, Estado Lara, Venezuela. Bioagro 21: 223-226.

Cirelli, K. R. N. \& A. M. Penteado-Dias. 2003. Fenologia dos Braconidae (Hymenoptera: Ichneumonoidea) da Área de Proteção Ambiental (APA) de Descalvado, SP. Revista Brasileira de Entomologia 47: 99-105.

Delfín González, H. \& D. Burgos Ruíz. 2000. Los braconidos (Hymenoptera: Braconidae) como grupo parámetro de biodiversidad en las selvas deciduas del trópico: una discusión acerca de su posible uso. Acta Zoológica Mexicana 79: 43-56.

Dolphin, K. \& D. L. J. Quicke. 2001. Estimating the global species richness of an incompletely described taxon: an example using parasitoid wasps (Hymenoptera: Braconidae). Biological Journal of the Linnean Society 73: 279-286.

Elpino-Campos, A.; K. Del-Claro \& F. Prezoto. 2007. Diversity of social wasps (Hymenoptera: Vespidae) in Cerrado fragments of Uberlandia, Minas Gerais state, Brazil. Neotropical Entomology 36: 685-692.

Falcó-Garí, J. V.; M. T. Oltra-Moscardó; J. Moreno-Marí; J. Pujade-Villar \& R. Jiménez-Peydró. 2006. Fenología de los bracónidos (Hymenoptera, Braconidae) del Pirineo andorrano. Pirineos 161: 111-132.

González, J. A.; M. A. M. Tomé; S. F. Gayubo \& F. Torres. 2000. Himenópteros aculeados capturados mediante trampas Malaise en un sector arenoso de la Submeseta Norte (España) (Hymenoptera, Aculeata). Nouvelle revue d' Entomologie 17: 337-353.

Kremen, C.; R. K. Colwell; T. L. Erwin; D. D. Murphy; R. F. Noss \& M. A. Saujayan. 1993. Terrestrial arthropod assemblages: their use as indicators in conservation planning. Conservation Biology 7: 796-808.

La Salle, J. \& I. D. Gauld. 1992. Parasitic Hymenoptera and the biodiversity crisis. Redia 74: 315-334.

Magurran, A. E. 1991. Ecological diversity and its measurenment. London, Chapman and Hall, $179 \mathrm{p}$

Martínez de Murguía, L.; M. A. Vázquez, \& J. L. Nieves-Aldrey. 2001. The families of Hymenoptera (Insecta) in an heterogeneous acidofilous forest in Artikutza (Navarra, Spain). Frustula Entomologica 24: 81-98.

Matthews, E. G. 1974. A revision of the scarabaeine dung beetles of Australia: II. Tribe Scarabaeini. Australian Journal of Zoology Supplementary Series 24: 1-211.

Moreno, C. 2001. Métodos para medir la biodiversidad. Zaragoza (M6TManuales y Tesis SEA), 84 p.

Nieves-Aldrey, J. L. \& C. Rey del Castillo. 1991. Ensayo preliminar sobre la captura de insectos por medio de una trampa Malaise en la Sierra de Guadarrama (España) con especial referencia a los himenópteros (Insecta, Hymenoptera). Ecología 5: 383-403.

Pearson, D. L. \& F. Cassola. 1992. World-wide species richness patterns of tiger-beetles (Coleoptera: Cicindelidae): Indicator taxon for biodiversity and conservation studies. Conservation Biology 6: 376-391.

Pujade-Villar, J. 1996. Resultados preliminares obtenidos a partir de una trampa Malaise situada en una zona mediterránea pirenaica. Pirineos 147-148: 61-80.

Pyle, R.; M. Bentzien \& P. Opler. 1981. Insect conservation. Annual Review of Entomology 26: 233-258.

Ros-Farré, P. \& J. Pujade-Villar. 1998. Estudio mediante una trampa Malaise de la comunidad de cinípidos cecidógenos e inquilinos de Santa Coloma, Andorra (Hymenoptera, Cynipidae). Ecología 12: 441-454. 
Scatolini, D. \& A. M. Penteado-Dias. 2003. Análise faunística de Braconidae (Hymenoptera) em três áreas de mata nativa do Paraná, Brasil. Revista Brasileira de Entomologia 47: 187-195.

Schluter, D. \& R. E. Ricklefs. 1993. Species diversity: an introduction to the problem, p. 1-10. In: R. E. Ricklefs y D. Schluter (eds.). Species diversity in ecological communities. Chicago, University of Chicago Press.

Segade, C.; P. Ros-Farré; A. Algarra; D. Ventura \& J. Pujade-Villar. 1997. Estudio comparativo de las capturas realizadas con trampa Malaise en Andorra con especial atención a los himenópteros (Hymenoptera). Zapateri (Revista Aragonesa de Entomología) 7: 71-82.

Sharkey, M. J. 1993. Family Braconidae, p. 362-395 In: Goulet, H. \& J. T. Huber (eds.). Hymenoptera of the World: An Identification Guide to Families. Agriculture Canada, 668 p.

Tobias, V. I.; Belokobylskii, S. A. \& A. G. Kotenko. 1986a. Family Braconidae. In: Medvedev, G. S. (ed.). Keys to the Insects of the European Part of the USSR, III. Part IV. Leningrad, Nauca Publisher, 500 p. (in Russian, English translation in 1995).

Tobias, V. I.; Jakimavicius, A. B. \& I. G. Kiriyak. 1986b. Family Braconidae. In: Medvedev, G. S. (ed.). Keys to the Insects of the European Part of the USSR, III. Part V. Leningrad, Nauca Publisher, 507 p. (in Russian, English translation in 1995).
Tomé, M. A. M.; J. A. González; S. F. Gayubo \& F. Torres. 2001. Estudio comparativo sobre la eficiencia de captura de insectos (Arthropoda, Hexapoda) mediante trampas Malaise, en un biotopo arenoso de la submeseta Norte (España). Boletín de la Real Sociedad Española de Historia Natural, Sección Biológica 96: 231-241.

Torezan-Silingardi, H. M. 2011. Predatory Behavior of Pachodynerus brevithorax (Hymenoptera: Vespidae, Eumeninae) on Endophytic Herbivore Beetles in the Brazilian Tropical Savanna. Sociobiology 57: 181-189.

Villarreal, H.; H. M. Alvarez; S. Córdoba; F. Escobar; G. Fagua; F. Gast; H. Mendoza; M. Ospina \& A. M. Umaña. 2004. Insectos, p. 149-184. In: Manual de métodos para el desarrollo de inventarios de biodiversidad. Bogotá, Instituto de Investigación de Recursos Biológicos Alexander von Humboldt.

Wharton, R. A.; P. M. Marsh \& M. J. Sharkey. 1997. Manual of the New World Genera of the Family Braconidae (Hymenoptera). No. 1, Special Publication of the International Society of Hymenopterists, $439 \mathrm{p}$.

Wharton, R. A.; P. M. Marsh; M. J. Sharkey \& I. Mercado. 1998. Manual para los Géneros de la Familia Braconidae (Hymenoptera) del Nuevo Mundo. Special Publication of the International Society of Hymenopterists (Spanish edition of 1997 publication above), $447 \mathrm{p}$.

Received 24/1/2011; accepted 5/8/2011

Editor: Kleber Del Claro 